\title{
PENGUKURAN AKUSTIK TARGET STRENGTH IKAN SELAR BENTONG (Selar boops) SECARA TERKONTROL DI PERAIRAN PULAU TIKUS KOTA BENGKULU
}

\author{
Deddy Bakhtiar, Lovita Nadia, Zamdial, Ari Anggoro \\ Program Studi Ilmu Kelautan, Fakultas Pertanian, Universitas Bengkulu, \\ Bengkulu, Indonesia \\ E-mail: deddybakhtiar@unib.ac.id
}

Received Agustus 2020, Accepted September 2020

\begin{abstract}
ABSTRAK
Metode akustik dapat digunakan dalam memperkirakan kelimpahan ikan. Metode ini membutuhkan informasi Target Strength (TS) untuk setiap spesies target. TS merupakan parameter penting sebagai faktor skala dalam pendugaan stok secara akustik. Penelitian ini bertujuan menganalisis karakteristik TS ikan selar bentong (Selar boops) dan mencari rumusan hubungan panjang baku dan panjang gelembung renang ikan selar bentong (Selar boops) terhadap nilai TS pada frekuensi transmisi $38 \mathrm{kHz}$. Pengukuran dilakukan secara terkontrol dimana ikan ditempatkan di bawah transduser dengan metode tethered menggunakan echosounder Simrad EK-60 pada frekeuensi $38 \mathrm{kHz}$. Hasil penelitian diperoleh nilai TS ikan selar bentong (Selar boops) berukuran panjang baku $16 \mathrm{~cm}$ sampai $20 \mathrm{~cm}$ menyebar pada kisaran $-51,62 \mathrm{~dB}$ sampai dengan $-39,03 \mathrm{~dB}$, dengan nilai rata - rata $-46,67 \mathrm{~dB}$. Model hubungan TS terhadap panjang baku ikan selar bentong yaitu TS $=30,1$ Log SL -84,49. Model hubungan TS terhadap panjang gelembung renang yaitu $\mathrm{TS}=$ 20,32 Log SB -62,34.
\end{abstract}

Kata Kunci : Panjang Baku Ikan, Gelembung Renang, Tethered Method, Echogram

\section{ABSTRACT}

ACOUSTIC CONTROLLED MEASUREMENT OF TARGET STRENGTH OF SELAR BENTONG FISH (SELAR BOOPS) IN TIKUS ISLAND WATER, BENGKULU CITY. Acoustic methods can be used to estimate fish abundance. This method requires Target Strength (TS) information for each target species. TS is an important parameter as a scale factor in acoustic estimation of stock. This study aims to analyze the TS characteristics of Selar bentong fish (Selar boops) and look for the formulation of the relationship between the standard length and length of the swim bladder in Selar bentong fish (Selar boops) to the TS value at the transmission frequency of $38 \mathrm{kHz}$. Measurements were carried out in a controlled manner where the fish were placed under the transducer with a 
tethered method using the Simrad EK-60 echosounder at a frequency of $38 \mathrm{kHz}$. The results showed that the TS value of Selar bentong (Selar boops) with a standard length of $16 \mathrm{~cm}$ to $20 \mathrm{~cm}$ spread over the range of $-51.62 d B$ to $-39.03 d B$, with an average value of $-46.67 d B$. The relationship model of TS to the standard length of Selar bentong fish was $T S=30.1$ Log SL -84.49. The relationship model of TS to swim bladder length was $T S=20.32 \log S B-62.34$.

Keywords : Standard Length of Fish, Swimbladder, Tethered Method, Echogram

\section{PENDAHULUAN}

Ikan Selar Bentong (Selar boops) merupakan jenis ikan dari famili Carangidae. Carangidae merupakan salah satu famili ikan yang memiliki distribusi luas di seluruh dunia dan diwakili oleh sekitar 140 spesies yang termasuk dalam 32 genera. Ikan ini membentuk kumpulan kelompok ikan yang sangat beragam dengan ukuran bervariasi dari sangat kecil hingga besar yang memiliki karakteristik morfologi dan meristik yang kompleks (Abdussamad et al., 2013). Ikan selar bentong termasuk kelompok sumberdaya ikan pelagis kecil yang hidup bergerombol, dimana daerah penyebarannya berada pada wilayah perairan pantai sampai kedalaman 80 meter, hidup di lingkungan perairan pantai landas kontinen (Cervirgon et al., 1992; Saranga et al., 2019).

Ikan komersial dari famili Carangidae terutama ikan selar bentong merupakan ikan ekonomis penting yang biasa ditangkap oleh nelayan di perairan pulau Tikus Kota Bengkulu (perairan Barat Sumatera) demikian pula bagi nelayan di perairan Bangka Belitung (perairan Timur Sumatera) (Akbar et al. 2018). Ikan ini secara khas mendiami terumbu karang dangkal (Iwatsuki et al., 2000) dimana perairan pulau Tikus merupakan perairan dengan hamparan terumbu karang yang luas sehingga menjadi habitat pencarian makan (feeding ground) bagi ikan selar bentong. Penangkapan ikan selar bentong yang telah dilakukan nelayan sejak lama dan cenderung meningkat jumlah penangkapan dan upaya penangkapannya. Agar pemanfaatan sumberdaya ikan selar bentong tersebut dapat berkelanjutan, maka perlu upaya pengelolaan pemanfaatannya secara lestari.

Salah satu prioritas utama dalam strategi pengelolaan sumberdaya perikanan berbasis ekosistem adalah membuat basis data perikanan (Susilowati 2013). Data potensi dan produksi ikan sangat penting sebagai dasar pengelolaan, terutama yang berkaitan dengan pemberian ijin penangkapan ikan. Menurut MacLennan (1990), pengelolaan sumberdaya perikanan yang baik harus mengontrol jumlah hasil tangkapan dalam hubungannya dengan jumlah stok ikan yang dapat dieksploitasi. Untuk perkiraan jumlah stok ikan saat ini teknik survei akustik dapat digunakan dalam memperkirakan kelimpahan ikan. Teknik pendugaan secara akustik membutuhkan data hambur balik akustik atau Target Strength (TS) untuk setiap spesies target (Dawson dan Karp 1990; Benoit-Bird et al., 2003; 
Zare et al., 2017). TS merupakan parameter penting dalam pendugaan sumberdaya secara akustik (Ona 2003; Kang et al., 2009). Oleh karena itu penelitian ini dilakukan pengukuran TS pada ikan selar bentong dengan tujuan menganalisis karakteristik hambur balik akustik (Target Strength) ikan selar bentong (Selar boops) di perairan Pulau Tikus Kota Bengkulu pada frekuensi transmisi $38 \mathrm{kHz}$; dan mencari rumusan hubungan panjang baku dan panjang gelembung renang ikan selar bentong (Selar boops) terhadap nilai Target Strength (TS) akustik pada frekuensi transmisi $38 \mathrm{kHz}$.

\section{MATERI DAN METODE}

\section{Waktu dan Tempat Penelitian}

Waktu pengukuran dilakukan dalam dua masa berbeda yaitu pada bulan Juli 2017. Pengukuran menggunakan alat echosounder pada frekuensi $38 \mathrm{kHz}$. Penelitian ini dilaksanakan di perairan Pulau Tikus Kota Bengkulu yang berjarak sekitar $9 \mathrm{~km}$ dari Kota Bengkulu. Lokasi penelitian merupakan laguna perairan terumbu karang yang relatif tenang dan dalam (kedalaman sekitar 12 meter).

\section{Alat dan Bahan}

Peralatan utama yang digunakan dalam penelitian ini adalah scientific echosounder Simrad EK-60 dengan frekuensi 38 kHz (parameter alat lihat Tabel 1). Bahan penelitian berupa jenis ikan selar bentong (Selar boops) (Gambar 1) dengan jumlah ikan digunakan sebanyak 5 ekor sampel yang diukur pada frekuensi $38 \mathrm{kHz}$.

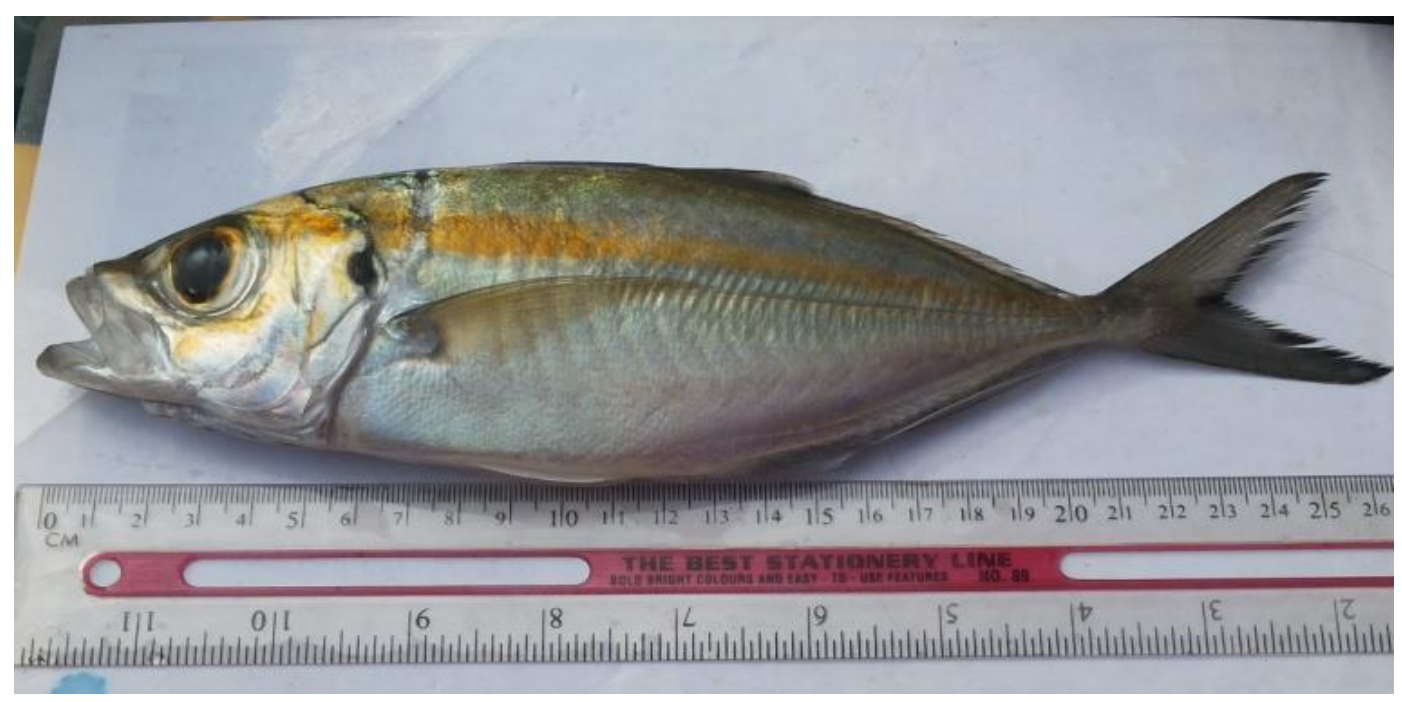

Gambar 1. Ikan elar bentong (Selar boops)

Sebelum melakukan pengukuran dan sounding terhadap ikan penelitian, peralatan akustik yang sudah terpasang terlebih dahulu 
dikalibrasi. Kalibrasi echosounder dilakukan dengan metode target standar (Foote et al., 1987) menggunakan bola copper ukuran $60 \mathrm{~mm}$ untuk frekuensi $38 \mathrm{kHz}$ yang ditempatkan pada sumbu akustik dari transduser. Pengukuran pada frekuensi $38 \mathrm{kHz}$ (bulan Juli) dilakukan di lokasi penelitian pada kedalaman perairan 12 meter dengan kondisi temperatur perairan $31^{\circ} \mathrm{C}$ dan salinitas $35 \%$.

Tabel 1. Parameter dan setting alat echosounder yang digunakan

\begin{tabular}{lll}
\hline Parameter & satuan & Simrad EK-60 \\
\hline Frequency & $\mathrm{kHz}$ & 38 \\
Transducer gain & $\mathrm{dB}$ & 23 \\
Transmit Power & Watt & 150 \\
Beam width & degree & 9.6 \\
Pulse length & $\mathrm{ms}$ & 0.512 \\
Absorption Coefficient & $\mathrm{dB} / \mathrm{m}$ & 0.0084 \\
Sound speed & $\mathrm{m} / \mathrm{s}$ & 1514.2 \\
TS Standard & $\mathrm{dB}$ & -33.6 \\
Diameter sphere & $\mathrm{mm}$ & 60 \\
Diameter transduser & $\mathrm{mm}$ & 336.5 \\
Jenis sphere & & Copper $(\mathrm{Cu})$ \\
Minimum threshold & $\mathrm{dB}$ & -60 \\
\hline
\end{tabular}

\section{Pengambilan Data}

Pengumpulan dilakukan di atas platform apung di perairan Pulau Tikus. CPU dan transceiver (GPT) diletakkan di atas platform apung selama akuisisi data sedangkan transducer diletakkan di bawah permukaan pada kedalaman $100 \mathrm{~cm}$. Pengukuran ikan tunggal (TS) menggunakan metode gantung (tethered method). Ikan uji digantung menggunakan tali nylon dengan jarak 4 meter dari transduser. Pemberat diletakkan pada ujung tali nylon dengan jarak 3 meter dari ikan uji (Gambar 2).

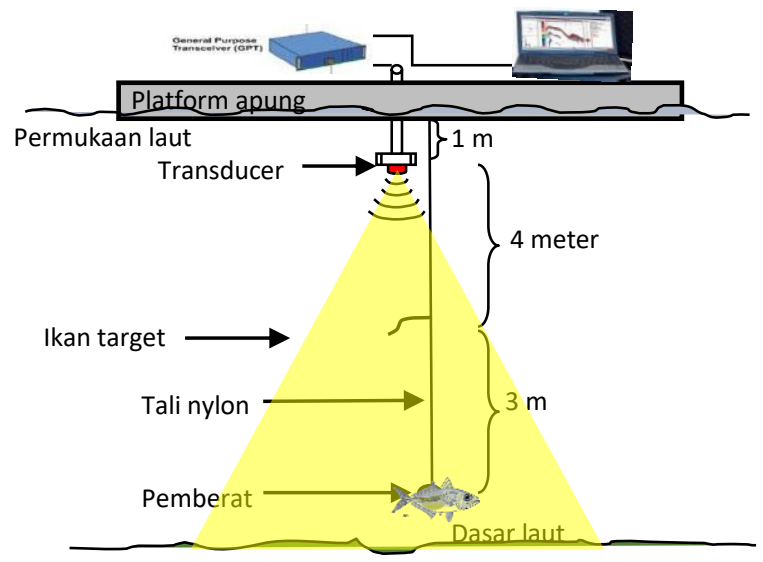

Gambar 2. Rancangan pengambilan data untuk pengukuran hambur balik (Target Strength) ikan selar bentong 
Penempatan ikan uji di bawah transduser dipastikan sudah berada di luar daerah near field. Jarak daerah near field dihitung berdasarkan persamaan :

$$
D=L^{2} / \lambda
$$

Dimana $L$ adalah diameter transduser dan $\lambda$ adalah panjang gelombang suara (Medwin dan Clay 1998). Berdasarkan persamaan (1) jarak daerah near field pada frekuensi $38 \mathrm{kHz}$ sebesar 2,83 $\mathrm{m}$ (diameter transduser $0.336 \mathrm{~m}$ ).

Perekaman data dilakukan satu persatu untuk tiap ikan sebanyak 5 ekor. TS diukur pada dorsal aspect-nya dimana ikan dalam kondisi hidup (live fish). Perekaman data dilakukan selama 5 menit untuk tiap individu ikan dan berulang pada individu ikan lainnya. Setiap ikan yang sudah disounding kemudian dilepaskan dari kaitannya untuk diukur panjang baku (Standard Lenghth, SL) dan dilakukan pembedahan untuk mengukur panjang gelembung renang (swimbladder, SB).

\section{Analisis Data}

\section{Analisis Hambur Balik Akustik}

Raw data yang diperoleh dari hasil perekaman melalui software ER 60 lalu dianalisis melalui software Echoview dengan minimum threshold $60 \mathrm{~dB}$ untuk mendapatkan nilai TS tiap ping. Nilai TS yang diperoleh tiap ping diubah dalam bentuk linear menjadi backscattering cross section $\left(\sigma_{\mathrm{bs}}\right)$ dan dihitung nilai rata-rata backscttering cross section $\left(\left\langle\sigma_{b s}\right\rangle\right)$ sebagai berikut:

$$
\begin{aligned}
& \sigma_{b s i}=10^{(T S i / 10)} \\
& <\sigma_{b s}>=\left(\sum_{i=1}^{n} \sigma_{b s i}\right) / n \\
& <\mathrm{TS}>=10 \log <\sigma_{b s}>
\end{aligned}
$$

Dimana $\sigma_{\text {bsi }}$ nilai backscattering cross section untuk ping ke-i; TSi adalah nilai Target Strength untuk ping ke-i; $\mathrm{n}$ adalah jumlah ping; kemudian $\left\langle\sigma_{b s}\right\rangle$ adalah rata-rata backscattering cross section tiap jenis ikan dan <TS> adalah rata-rata Target Strength untuk tiap jenis ikan.

\section{Analisis Hubungan TS terhadap Panjang Baku Ikan dan Gelembung Renang}

Analisis Regresi Linear Sederhana akan menghasilkan model hubungan linear antara TS sebagai peubah tak bebas dan ukuran panjang baku ikan (SL, standard length) sebagai peubah bebas. Model hubungan linear yang digunakan mengikuti persamaan Love (1969, 1971):

$\sigma=\mathrm{aL}^{\mathrm{b}}$, dalam bentuk logaritmik menjadi:

$\mathrm{TS}=\mathrm{b} \log \mathrm{L}_{S L}+\mathrm{a} \quad[\mathrm{dB}]$ 
Dimana $\sigma$ adalah hambur balik akustik (acoustic backscattering), $\mathrm{L}$ adalah ukuran panjang target, $L_{S L}$ adalah ukuran panjang baku ikan, a adalah intersep dari persamaan regresi dan $b$ adalah slope dari persamaan regresi. Model regresi yang telah diperoleh dari persamaan (5) kemudian diuji lebih lanjut menggunakan Analisis Varian (uji-F).

Analisis Regresi Linear Sederhana juga pada hubungan linear antara TS sebagai peubah tak bebas dan ukuran panjang gelembung renang (SB, swimbaldder) sebagai peubah bebas. Model hubungan linear yang digunakan mengikuti persamaan Love (1969, 1971):

$\sigma=\mathrm{aL}^{\mathrm{b}}$, dalam bentuk logaritmik menjadi:

$\mathrm{TS}=\mathrm{b} \log \mathrm{L}_{\mathrm{SB}}+\mathrm{a}[\mathrm{dB}]$

Dimana $\sigma$ adalah hambur balik akustik (acoustic backscattering), L adalah ukuran panjang target, $L_{S B}$ adalah ukuran panjang gelembung renang, a adalah intersep dari persamaan regresi dan b adalah slope dari persamaan regresi. Model regresi yang telah diperoleh dari persamaan (6) kemudian diuji lebih lanjut menggunakan Analisis Varian (uji-F).

\section{HASIL DAN PEMBAHASAN}

\section{Karakteristik Target Strength}

Pendugaan nilai Target Strength ikan merupakan salah satu cara dalam estimasi stok ikan di suatu wilayah perairan. Nilai Target Strength merupakan parameter utama pada aplikasi akustik dalam menduga kelimpahan ikan di suatu perairan. Pada (Gambar 3) dapat dilihat hasil echogram setelah kegiatan pendeteksian ikan selar bentong di perairan Pulau Tikus Kota Bengkulu.

Nilai Target Strength rata-rata yang dihasilkan dari pengolahan echogram pada setiap ikan Selar boops (Gambar 3) yang digunakan menghasilkan nilai Target Strength yang bervariasi. Sebaran nilai Target Strength dari kelima ikan Selar boops tersebut tersaji dalam Tabel 2 sebagai berikut.

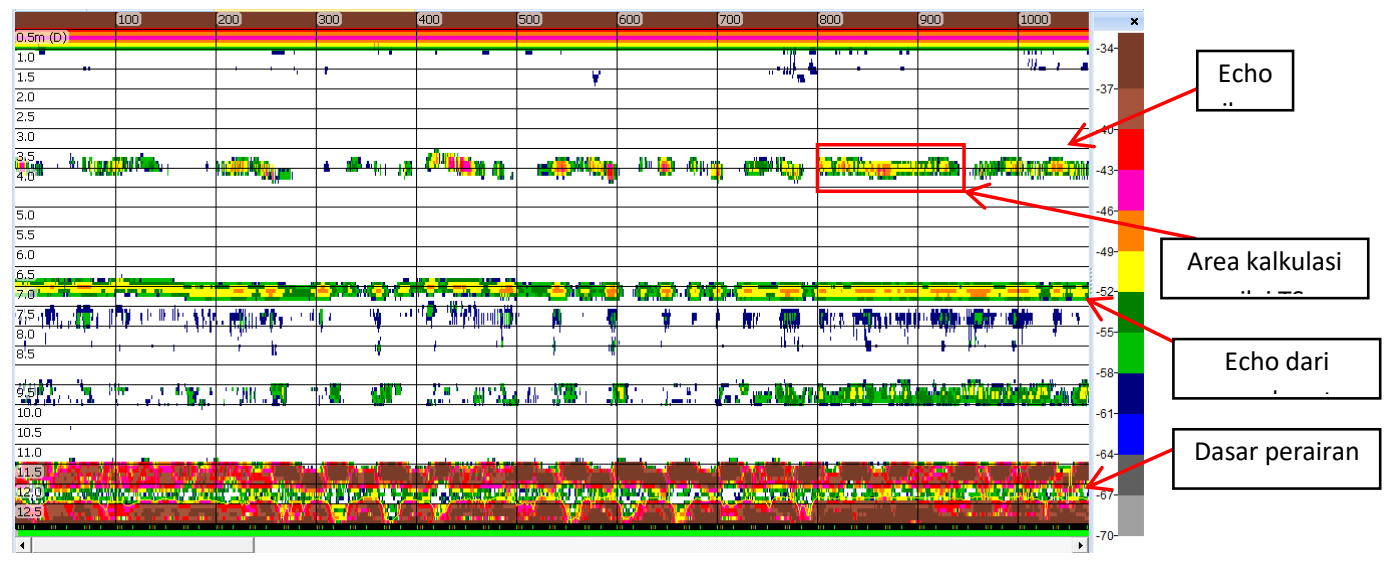

Gambar 3. Echogram dari hasil pengukuran TS ikan selar bentong 
Tabel 2. Kisaran nilai TS ikan selar bentong yang diukur di perairan Pulau Tikus

\begin{tabular}{cccc}
\hline \multirow{2}{*}{ Ikan ke- } & Min & TS (dB)) & $\begin{array}{c}\text { Rata - Rata } \\
\text { TS (dB) }\end{array}$ \\
\hline 1 & $-51,60$ & Max & -48.09 \\
2 & $-50,00$ & $-41,00$ & -45.37 \\
3 & $-50,33$ & $-39,80$ & -46.02 \\
4 & $-50,00$ & $-39,70$ & -46.67 \\
5 & $-50,00$ & $-42,66$ & -47.82 \\
\hline \multicolumn{4}{c}{ Rata-rata TS seluruh ikan } \\
\hline
\end{tabular}

Tabel 2 memperlihatkan nilai rata-rata TS dari keseluruahn ikan selar bentong (Selar boops) adalah $-46,67 \mathrm{~dB}$, informasi nilai rata-rata TS ini penting diketahui sebagai dasar dalam pendugaan biomassa sebagaimana dikemukakan Boswell et al.(2008) bahwa mengubah energi akustik dalam bentuk TS menjadi biomassa ikan melibatkan beberapa langkah: (1) memperkirakan rata-rata TS dari data yang diamati; (2) memperkirakan kepadatan ikan akustik; (3) mengkonversi rata-rata TS menjadi panjang ikan; (4) mengubah panjang rata-rata menjadi berat badan; dan (5) menghitung biomassa ikan dengan mengalikan densitas rata-rata dengan berat rata-rata. Akibatnya, jika salah satu dari perkiraan ini tidak akurat, kesalahan akan menyebar dan menghasilkan perkiraan biomassa yang samar-samar

\section{Hubungan Target Strength (TS) terhadap Ukuran Panjang Ikan}

Telah banyak penelitian yang menjelaskan tentang hubungan nilai Target Strength terhadap ukuran panjang ikan. Ukuran panjang ikan merupakan salah satu faktor yang sangat berpengaruh terhadap nilai Target Strength ikan. Berdasarkan hasil pengolahan data terhadap lima ikan Selar boops dengan spesies yang sama namun berbeda ukuran, terdapat hubungan linier positif antara nilai Target Strength dengan panjang ikan.

Gambar 4 terlihat bahwa nilai Target Strength rata-rata ikan berhubungan linier positif terhadap ukuran panjang baku ikan selar bentong. Hal ini ditunjukkan dengan nilai koefisien korelasi $(r$ ) yaitu 0,95 atau nilai koefesien determinasi $\left(R^{2}\right)$ sebesar 0,91 yang berarti $91 \%$ nilai TS dipengaruhi oleh faktor panjang baku ikan. Hubungan nilai TS dan ukuran pajang baku ikan selar bentong (Selar boops) dituangkan dengan persamaan $\mathrm{TS}=30,01 \mathrm{Log} \mathrm{SL}-84,5$. Berdasarkan persamaan tersebut menunjukkan nilai slope sebesar 30,01 tidak mereprentasikan kuadrat panjang ikan atau $20 \log \mathrm{L}$, hal yang sama juga dikemukakan McClatchie et al. (1996) sebagian besar spesies tidak sesuai dengan ketergantungan kuadrat dari TS terhadap panjang ikan. Sedangkan pada ikan Pomfret dan silver sprat menunjukkan kecocokan paling dekat dengan ketergantungan kuadrat, rata-rata slope untuk sebagian besar spesies jatuh antara 15 dan 25. 


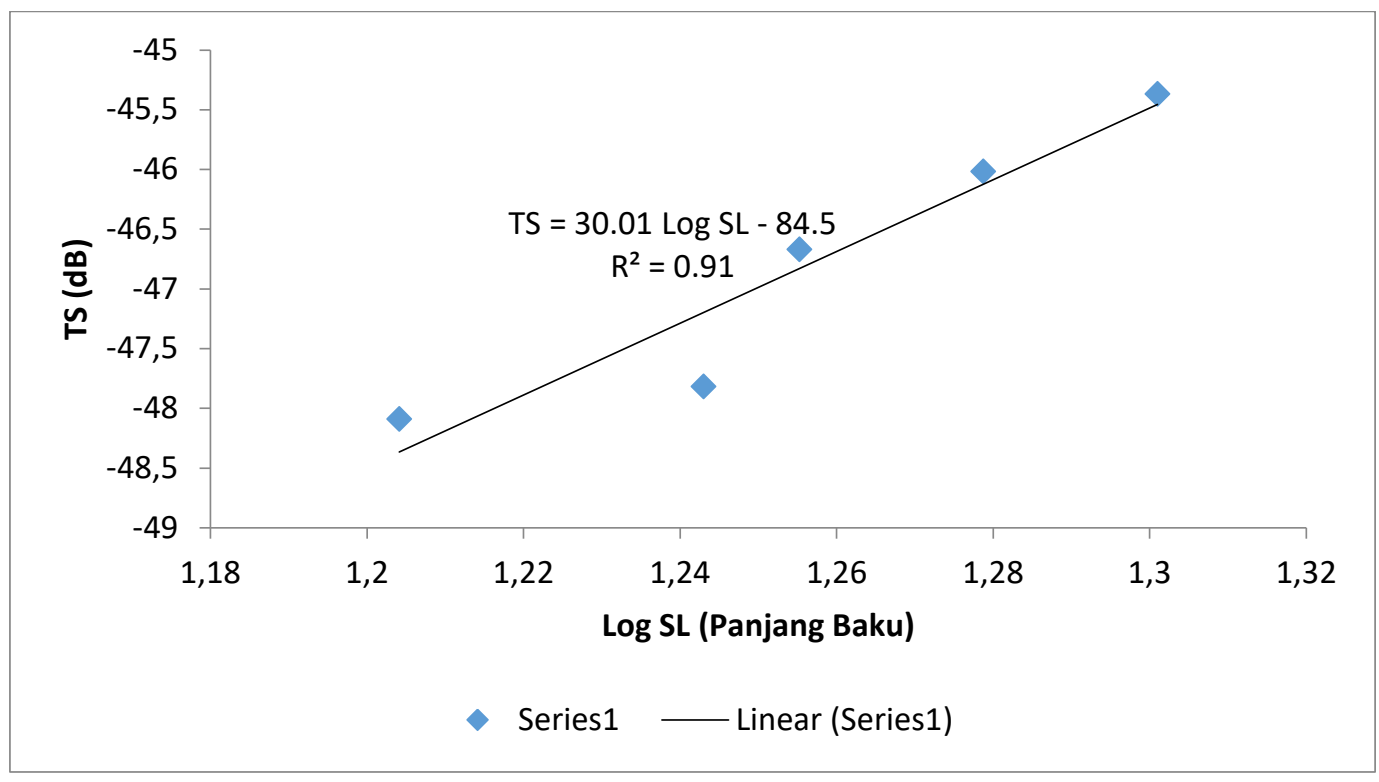

Gambar 4. Hubungan linier Target Strength terhadap panjang ikan selar bentong

Gambar 4 memperlihatkan perubahan nilai TS sejalan dengan perubahan ukuran panjang baku ikan, terdapat hubungan linear positif antara nilai Target Strength dengan ukuran panjang ikan. TS individu ikan tergantung pada parameter morfologi tubuhnya, seperti panjang, berat badan, kandungan lemak, perkembangan dan kehadiran gonad, ukuran dan jenis gelembung renang (Ona, 1990; Hazen dan Horne, 2003). Hal yang sama dikemukakan Frouzova et al. (2005) yang menjelaskan bhwa ukuran panjang total ikan dan jenis spesies ikan memberikan kontribusi signifikan terhadap TS yang dihasilkan dan ukuran panjang ikan adalah prediktor utama dari TS

\section{Hubungan Target Strength (TS) terhadap Gelembung Renang}

Gambar 5 menunjukkan hubungan linier antara nilai Target Strength terhadap gelembung renang. Nilai Target Strength rata-rata ikan berhubungan linier positif terhadap ukuran gelembung renang dengan nilai koefisien korelasi ( $r$ ) yaitu 0,94 dan koefesien determinasi $\left(R^{2}\right)$ sebesar 0,89 yang berarti $89 \%$ nilai TS dipengaruhi ukuran gelembung renang. Hubungan TS dan ukuran gelembung renang dituangkan dalam bentuk persamaan $T S=20,32 \log S B-62,34$.

Gambar 5 hubungan antara nilai Target Strength dengan ukuran panjang gelembung renang ikan selar bentong (Selar boops) berkolerasi positif dan kategori hubungannya tergolong sangat kuat. Hal ini menunjukkan bahwa gelembung renang juga memberikan variasi terhadap nilai rata-rata TS dari ikan selar bentong. Variasi pada tubuh dan lebar gelembung renang, kedalaman, dan bentuk mempengaruhi jumlah energi backscattered dari ikan (Ona, 1990; Ona et al., 2001). Perubahan kepadatan tubuh, volume gelembung renang dan perilaku yang 
dimanifestasikan melalui sudut aspek dan sudut putar adalah semua faktor potensial yang dapat memengaruhi Target Strength (Horne et al. 2000).

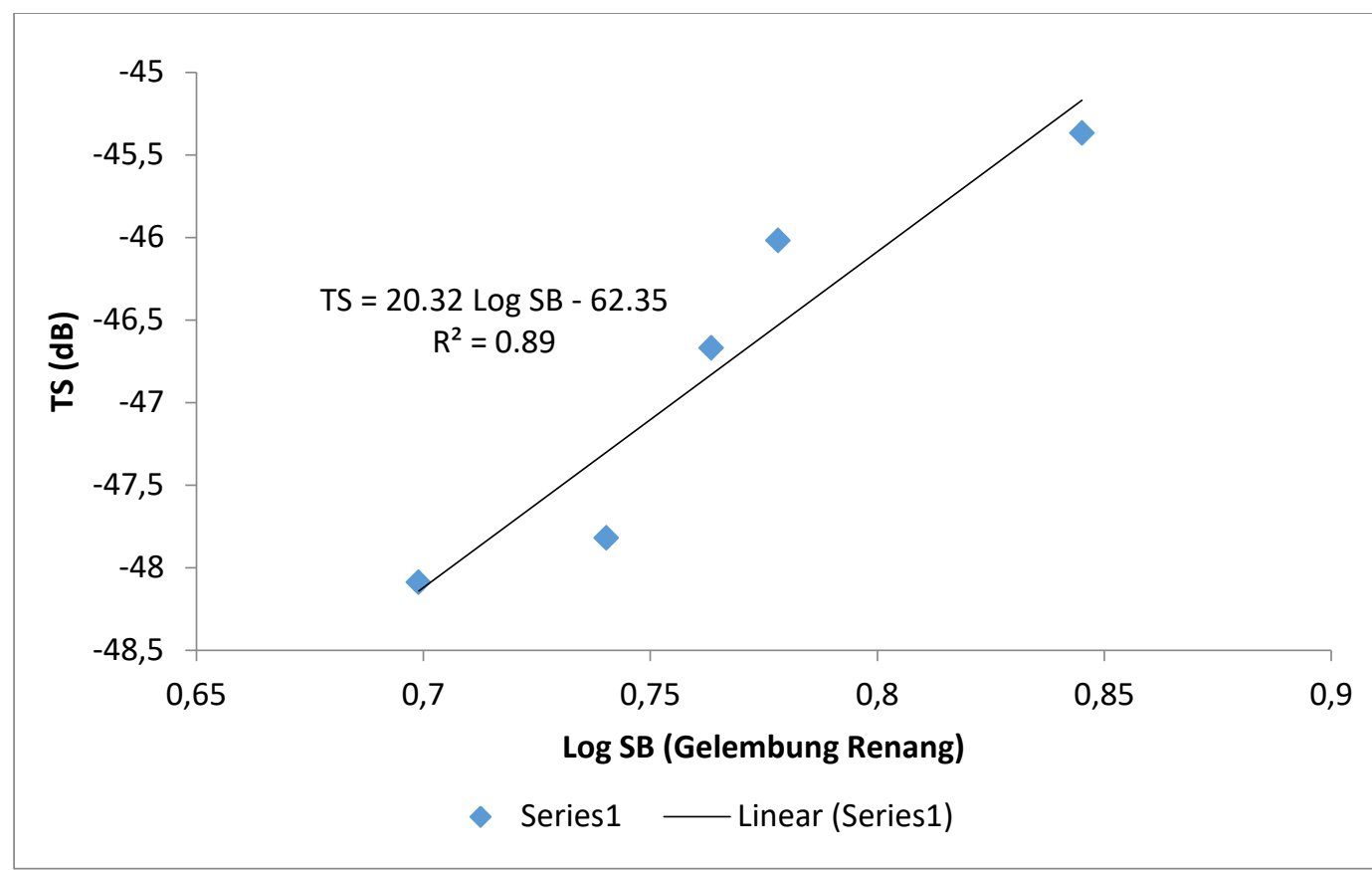

Gambar 5. Hubungan linier TS terhadap gelembung renang ikan selar bentong

Hasil pengukuran ikan selar bentong juga menunjukkan pengaruh terhadap ukuran gelembung renang ikan. Terlihat bahwa semakin besar ukuran ikan maka akan semakin besar pula ukuran gelembung renang. Gelembung renang ini sangat berpengaruh terhadap nilai pantulan dari sinyal akustik dimana ikan yang memiliki gelembung renang memiliki nilai Target Strength yang lebih besar dari pada ikan tanpa gelembung renang. Mitson (1983) menyatakan bahwa ikan dengan gelembung renang akan mengembalikan signal echo lebih dari $50 \%$ walaupun volume gelembung renang tersebut hanya menempati $5 \%$ dari volume ikan.

Perubahan nilai TS berdasarkan ukuran gelembung renang juga sejalan dengan perubahan ukuran panjang ikan, sehingga persamaan hubungannya juga diperkirakan merefleksikan kuadrat ukuran panjang ikan (20 log L). Sobradillo et al. (2019) melaporkan TS yang diperoleh versus hubungan panjang dalam penelitian ini menunjukkan konsistensi dengan korelasi positif dan signifikan yang ditemukan antara panjang standar ikan dan volume gelembung renang. Korelasi positif ditemukan antara ukuran gelembung renang dan panjang tubuh, sesuai dengan peningkatan hubungan panjang-TS yang diamati. Namun, McClatchie et al. (2003) mendapatkan hasil dari data pemodelan gelembung renang menunjukkan bahwa lima dari 10 spesies tidak sesuai dengan hubungan $20 \log$ L. Ini menunjukkan bahwa banyak deviasi dari hubungan $20 \log 10$ L. 
Deviasi dan variabilitas hubungan $20 \log \mathrm{L}$ diperkirakan juga disebabkan faktor fisiologis dari ikan seperti kandungan lemak dan gonad pada ikan. Ona (1990) mengemukakan ketika gonad tumbuh, ada kompresi bertahap dari gelembung renang yang mengandung gas, yang dapat menambah atau mengurangi area dorsal efektif dari swimbladder tergantung pada spesies. Kemudian Zare et al. (2017) menemukan bahwa rata-rata TS dapat berbeda sebanyak $4 \mathrm{~dB}$ untuk ikan dengan ukuran yang sama, yang menyiratkan bahwa faktor selain ukuran berkontribusi secara substansial terhadap variabilitas pada TS Anchovy kilka. Sumber utama variabilitas TS tampaknya terkait dengan persentase kematangan betina dalam sampel, menunjukkan bahwa perbedaan dalam karakteristik seksual mempengaruhi sifat akustik individu dalam spesies ini. Penelitian sebelumnya telah melaporkan bahwa organ gonad dapat meningkatkan atau menurunkan efek pada gelembung renang, akhirnya mempengaruhi TS, pada spesies yang berbeda (Ona, 1990).

\section{KESIMPULAN}

Nilai Target Strength (TS) ikan selar bentong (Selar boops) menyebar pada nilai Target Strength $-51,62 \mathrm{~dB}$ sampai dengan -39,03 $\mathrm{dB}$, dengan nilai rata - rata TS ikan selar bentong yaitu $-46,67 \mathrm{~dB}$ pada kisaran panjang ikan $16 \mathrm{~cm}$ sampai dengan $20 \mathrm{~cm}$. Model hubungan Target Strength terhadap panjang ikan selar bentong secara regresi linier yaitu TS $=30,1$ Log SL -84,49. Model hubungan Target Strength terhadap gelembung renang secara regresi linier yaitu TS $=20,32$ Log SB -62,34.

\section{DAFTAR PUSTAKA}

Abdussamad E.M., Rohit, K. P. P. Koya, O. M. M. J. H. Mohamed dan K. Jeyabalan. 2013. Carangids (Family: Carangidae) in the seas around Indian subcontinent with description of macro-taxonomic characters for the field identification of genera and species.Indian J. Fish., 60(2) : 21-36.

Akbar H., Jailani, I. Suyatna, Destilawaty, S. A. Putra, I. Ambalika, 2018. Check list of the marine commercial and reef fishes of Belitung Timur, Bangka Belitung Islands, Indonesia Aceh Journal of Animal Science 3 (2): 69-83. DOI: 10.13170/ajas.3.2.12220.

Benoit-Bird KJ, Whitlow WLA, Christopher DK, Christopher T. 2003. Acoustic backscattering by deepwater fish measured in situ from a manned submersible. Deep-Sea Research I, 50: 221-229.

Boswell KM, Kaller MD, Cowan JH Jr, Wilson CA. 2008. Evaluation of Target Strength-fish length equation choices for estimating estuarine fish biomass. Hydrobiologia. 610:113-123. 
Cervirgon F, R. Cipriani, W. Fischer, L. Garibaldi, M. Hendrickx, A.J. Lemus, R. Marquez, J.M. Piutiers, G. Robaina \& B. Rodriguez. "Sheets FAO species identification for fishery purpose. Field guide to the commercial marine and brackish species aquas of the morthern coast of South America". FAO, Roma. 513p, 1992.

Dawson JJ, Karp WA. 1990. In situ measures of Target Strength variablelity of individual fish. Rapp. P.-V. Reun. Cons. Int. Explor. Mer. 189:264-273.

Foote KG, Knudsen HP, Vestnes GD, MacLennan N, Simmonds EJ, 1987. Calibration of acoustic instruments for fish density estimation: a practical guide. ICES Coop. Res. Rep. 144, 1-69.

Frouzova J, Kubecka J, Balk H, Frouz J. 2005. Target Strength of some Europeanfish species and its dependence on fish body parameters. Fish Res. 75: 86-96.

Hazen EL, Horne JK. 2003. A method for evaluating the effects of biological factors on fish Target Strength. ICES J Mar Sci. 60:555562.

Horne JK, P. D. Walline, and J. M. Jech. 2000. Comparing acoustic model predictions to in situ backscatter measurements of fish with dualchambered swimbladders. J. Fish Bio., 57:1105-1121. doi:10.1006/jfbi.2000.1372.

Iwatsuki, Y., M.I. Djawad, A.I. Burhanuddin, H. Motomura, K. Hidaka. 2000. A preliminary list of the epipelagic and inshore fishes of Makassar (=Ujung Pandang), South Sulawesi, Indonesia, collected mainly from fish markets between 23-27 January 2000, with notes on fishery catch characteristics. Bulletin of the Faculty of Agriculture, Miyaxaki University, 41(1-2): 95-114.

Kang D, Cho S, Lee C, Myoung JG, Na J. 2009. Ex situ target-strength measurements of Japanese anchovy (Engraulis japonicus) in the coastal Northwest Pacific. ICES J Mar Sci. 66:1219-1224.

Love $\mathrm{RH}$. 1969. Maximum Side-Aspect Target Strength of an Individual Fish. J Acoust. Soc. Am, 46(3):746-752.

Love $\mathrm{RH}$. 1971. Dorsal-aspect Target Strength of an individual fish. $J$ Acoust Soc Am. 49(3): 816-823.

MacLennan DN. 1990. Acoustical measurement of fish abundance. J Acoust Soc Am, 87: 1-15. 
McClatchie S, Alsop J, Coombs RF. 1996. A re-evaluation of relationshipsbetween fish size, acoustic frequency, and Target Strength. ICES J Mar Sci. 53:780-791.

McClatchie S, Macaulay GJ, Coombs RF. 2003. A requiem for the use of $20 \log 10$ Length for acoustic Target Strength with special reference to deep-sea fishes. ICES J Mar Sci. 60:419-428.

Medwin H dan Clay CS. 1998. Applied Ocean Acoustics: Fundamentals of Acoustical Oceanography. Academic Press, New York. 712 pp.

Mitson, R. B. 1983. Fisheries Sonar. Fishing News Book. England.

Ona E. 2003. An expanded target-strength relationship for herring. ICES J Mar Sci. 60:493-499.

Ona, E. 1990. Physiological factors causing natural variations in acoustic Target Strength of fish. Journal of the Marine Biological Association of the United Kingdom, 70: 107-127.

Ona, E., Svellingen, I., and Fosseidengen, J. E. 2001. Target Strength of herring during vertical excursions. ICES Fisheries Acoustic Science and Technology Working Group (FAST), Seattle, April, 2001: 1-16.

Saranga R., S. Simau, J. Kalesaran, M. Z. Arifin. 2019. Ukuran Pertama Kali Tertangkap, Ukuran Pertama Kali Matang Gonad dan Status Pengusahaan Selar boops di Perairan Bitung. Journal of Fisheries and Marine Research 3 (1):67-74.

Sobradillo B., G. Boyra, U. Martinez, P. Carrera, M. Peña \& X. Irigoien. 2019. Target Strength and swimbladder morphology of Mueller's pearlside (Maurolicus muelleri). Scientific Reports 9:17311. https://doi.org/10.1038/s41598-019-53819-6.

Susilowati I. 2013. Prospek Pengelolaan Sumber Daya Perikanan Berbasis Ekosistem: Studi Empiris Di Karimunjawa. J. Eko Pemb 14 (1) : 16-37.

Zare P, Kasatkina SM, Shibaev SV, Fazli H. 2017. In situ acoustic Target Strength of anchovy kilka (Clupeonella engrauliformis) in the Caspian Sea (Iran). Fish Res. $186:$ :311-318. 